\title{
FAKTOR YANG BERPENGARUH TERHADAP DISIPLIN KERJA GURU SMKN 1 DEPOK DAN SMKS YAPAN INDONESIA
}

\author{
Anna Nurfarhana, Agus Abdillah, Hendro Prasetyono \\ Dosen Program Studi Pendidikan Ekonomi Universitas Indraprasta PGRI \\ Email : annanurfarhana788@gmail.com,gusti_cokrodiningrat@yahoo.co.id, \\ hendro_prasetyono@unindra.ac.id
}

\begin{abstract}
Abstrak
Tujuan penelitian ini adalah untuk mengetahui dan menganalisis pengaruh peran kepemimpinan kepala sekolah, motivasi kerja dan kepuasan kerja terhadap disiplin kerja guru SMKN 1 Depok dan SMKS Yapan Indonesia baik secara langsung maupun tidak langsung. Populasi dari penelitian ini adalah seluruh guru kelompok bisnis dan manajemen di SMKN 1 Depok dan SMKS Yapan Indonesia yang berjumlah 120 orang. Dalam penelitian ini mengelompokkan guru berdasarkan pangkat/golongan/ruang, yaitu golongan III sebanyak 75 orang dan golongan IV sebanyak 45 orang. Metode pengambilan sampel dilakukan dengan menggunakan teknik stratified proportionated random sampling, sehingga diperoleh sampel sebanyak 90 orang. Pengumpulan data dilakukan dengan pengisian angket. Analisis data yang digunakan adalah analisis jalur. Pengolahan data dilakukan dengan SPSS versi 23.0. Hasil penelitian menunjukkan bahwa terdapat pengaruh yang signifikan antara peran kepemimpinan kepala sekolah terhadap motivasi kerja (1), peran kepemimpinan kepala sekolah terhadap kepuasan kerja (2), peran kepemimpinan kepala sekolah terhadap disiplin kerja guru (3), motivasi kerja terhadap kepuasan kerja (4) motivasi kerja terhadap disiplin kerja guru (5) dan kepuasan kerja terhadap disiplin kerja guru (6). Secara keseluruhan, baik secara langsung dan tidak langsung besarnya pengaruh diketahui 41,22\%, sedangkan sisanya sebesar 59,20\% dipengaruhi oleh faktor lain yang tidak diteliti dalam penelitian ini.

Kata kunci : Disiplin Kerja Guru, Kepuasan Kerja, Motivasi Kerja, Peran Kepemimpinan Kepala Sekolah.
\end{abstract}

\section{PENDAHULUAN}

Berbagai upaya telah dilakukan pemerintah untuk meningkatkan disiplin kerja guru. Upaya itu adalah meningkatkan mutu profesional guru melalui penataran, lokakarya, seminar dan sebagainya. Disamping itu mengoptimalkan musyawah guru mata pelajaran (MGMP), workshop serta peningkatan kesejahteraan guru dengan jalan memberikan tunjangan daerah dan sertifikasi. Semua tersebut dilakukan agar guru peduli dan puas dalam menjalankan tugas.

Walaupun pemerintah telah melakukan perbagai upaya, namun kenyataanya belum berhasil sesuai dangan apa yang diharapkan. Masih banyak terjadi kesenjangankesenjangan dalam pelaksanaan tugas sehari hari. Hal ini tercermin dari ketidakpuasan pihak-pihak yang berkepentingan, khususnya masyarakat dunia industri terhadap tamatan SMK. Masyarakat cendrung berpendapat bahwa mutu lulusan SMK masih rendah, tidak siap pakai, tidak ulet, kurang serius serta bermacam macam nada negatif lainnya. 
Masalah ketidakdisiplinan guru diduga menjadi salah satu penyebab rendahnya mutu pendidikan di SMK. Sikap guru yang tidak sungguh sungguh dalam melaksanakan tugasnya akan tercermin dalam penampilannya ketika mengajar. Bagaimanapun juga, sikap guru didepan kelas akan mempengaruhi respon siswa terhadap pelajaran yang diikutinya. Jika Guru sungguh sungguh dan antusias dalam mengajar, tepat waktu dan memperhatikan perkembangan siswa , maka siswa juga akan merespon dengan sungguh sungguh dan antusias karena merasa diperhatikan oleh guru.

Rendahnya Disiplin Guru diduga disebabkan oleh masalah Peran Kepemimpinan Kepala Sekolah, Motivasi Kerja, dan Kepuasan Kerja.

Tujuan dari penelitian ini adalah untuk mengetahui dan menganalisis pengaruh Peran Kepemimpinan Kepala Sekolah terhadap Motivasi Kerja Guru SMKN 1 Depok dan SMKS Yapan Indonesia, pengaruh Peran Kepemimpinan Kepala Sekolah terhadap Kepuasan Kerja Guru SMKN 1 Depok dan SMKS Yapan Indonesia, pengaruh Peran Kepemimpinan Kepala Sekolah terhadap Disiplin Kerja Guru SMKN 1 Depok dan SMKS Yapan Indonesia, pengaruh Motivasi Kerja terhadap Kepuasan Kerja Guru SMKN 1 Depok dan SMKS Yapan Indonesia dan pengaruh Motivasi Kerja terhadap Disiplin Kerja Guru SMKN 1 Depok dan SMKS Yapan Indonesia serta pengaruh Kepuasan Kerja terhadap Disiplin Kerja Guru SMKN 1 Depok dan SMKS Yapan Indonesia.

Manfaat yang diharapkan dari penelitian ini yaitu, memberikan pengaruh yang berdaya guna secara teoritis, metodologis dan empiris bagi kepentingan akademis dalam bidang pendidikan, dapat dijadikan suatu pola dan strategi dalam meningkatkan disiplin kerja guru. Bagi pengembangan ilmu pengetahuan, sebagai sarana pengembangan ilmu pengetahuan manajemen sumber daya manusia khususnya tentang pentingnya peran kepemimpinan, motivasi kerja, dan kepuasan kerja dalam meningkatkan disiplin kerja pegawai. Bagi Stakeholder, sebagai masukan kepada Dinas Pendidikan dan Sekolah dalam mengambil kebijakan terutama mengenai permasalah ini. Tulisan ini dijadikan salah satu sumber bacaan yang dapat dipertimbangkan dalam pemecahan masalah yang relevan.

Selanjutnya bagi peneliti lebih lanjut, sebagai tambahan referensi bagi masyarakat ilmiah yang berminat melakukan penelitian pada bidang yang sama khususnya mengenai masalah sumber daya manusia. 


\section{TINJAUAN PUSTAKA}

\section{Disiplin Kerja Guru}

Menurut Hasibuan (2012:193) kedisiplinan adalah kesadaran dan kesediaan seseorang menaati semua peraturan perusahaan dan norma sosial yang berlaku. Disiplin yang baik mencerminkan besarnya rasa tanggungjawab seseorang terhadap tugas tugas yang diberikannya. Hal tersebut mendorong gairah kerja dan terwujudnya tujuan perusahaan. Disiplin kerja merupakan tindakan manajemen untuk mendorong anggota organisasi memenuhi tuntutan berbagai ketentuan tersebut. Dengan kata lain, pendisiplinan pegawai adalah suatu bentuk pelatihan yang berusaha memperbaiki dan membentuk pengetahuan, sikap dan perilaku pegawai sehingga para pegawai tersebut secara sukarela berusaha bekerja secara kooperatif dengan para pegawai lainnya, serta meningkatkan prestasi kerja. Disiplin diarahkan untuk memperbaiki dan membentuk sikap serta perilaku pegawai secara sukarela untuk dapat bekerjasama dengan pegawai lainnya dalam meningkatkan prestasi kerjanya (Siagian, 2004:305).

Kemudian Menurut Rivai (2005:444) Disiplin kerja adalah suatu alat yang digunakan para manajer untuk berkomunikasi dengan pegawai agar mereka bersedia untuk mengubah suatu perilaku serta sebagai suatu upaya untuk meningkatkan kesadaran dan kesediaan seseorang mentaati semua peraturan perusahaan dan norma-norma sosial yang berlaku. Sedangkan menurut Mathis (2006:511) yang dimaksud dengan disiplin adalah bentuk pelatihan yang menjalankan peraturan organisasional.

Dari beberapa pendapat di atas, dapat disimpulkan bahwa kedisiplinan adalah kesadaran dan kesediaan seseorang menaati semua peraturan perusahaan dan normanorma sosial yang berlaku. Kesadaran disini merupakan sikap seseorang yang secara sukarela menaati semua peraturan dan sadar akan tugas dan tanggung jawabnya. Jadi, dia akan mematuhi atau mengerjakan semua tugasnya dengan baik, bukan atas paksaan.

\section{Kepuasan kerja}

Menurut Usman (2010:281) kepuasan kerja adalah sikap seseorang terhadap pekerjaannya yang mencerminkan pengalaman yang menyenangkan dan tidak menyenangkan dalam pekerjaannya serta harapan-harapannya terhadap pengalaman masa depan. Menurut Robbins (2009:107) “Secara umum kepuasan kerja didefinisikan sebagai suatu perasaan positif tentang pekerjaan seseorang yang merupakan hasil dari sebuah evaluasi karakteristiknya. Sedangkan menurut Anoraga (2004:180) kepuasan 
kerja mencerminkan perasaan seseorang terhadap pekerjaannya dan segala sesuatu yang dihadapi dalam lingkungan kerja.

Sedangkan menurut Hasibuan (2012:202) kepuasan kerja adalah sikap emosional yang menyenangkan dan mencintai pekerjaannya. Selanjutnya menurut Mangkunegara (2009:117) Pegawai akan merasa puas dalam bekerja apabila aspek-aspek pekerjaan dan aspek-aspek dirinya menyokong dan sebaliknya jika aspek-aspek tersebut tidak menyokong, pegawai akan merasa tidak puas.

Selanjutnya menurut Martoyo (2000:142) mengemukakan bahwa kepuasan kerja (job statsfaction) adalah keadaan emosional karyawan dimana terjadi ataupun tidak terjadi titik temu antara lain nilai balas jasa kerja karyawan dari perusahaan atau organisasi dengan tingkat nilai balas jasa yang memang diinginkan oleh karyawan ini, baik yang berupa finansial maupun non finansial.

Berdasarkan uraian diatas maka dapat disimpulkan bahwa kepuasan kerja adalah suatu perasaan seseorang terhadap pekerjaannya, dimana ia akan merasa puas apabila ada kesesuaian antara kemampuan, keterampilan, dan harapannya dengan pekerjaan yang ia hadapi. Kepuasan akan menghasilkan hasil yang semaksimal mungkin antara interaksi manusia dengan lingkungan kerjanya. Dengan demikian ia akan memberikan sumbangan yang optimal untuk mencapai tujuan.

\section{Motivasi Kerja}

Robbins dan Judge (2007:112) mendefinisikan motivasi kerja sebagai proses yang menjelaskan intensitas, arah dan ketekunan usaha untuk mencapai suatu tujuan. Selanjutnya Mangkunegara (2005:61) menyatakan bahwa motivasi terbentuk dari sikap (attitude) karyawan dalam menghadapi situasi kerja di perusahaan (situation). Motivasi merupakan kondisi atau energi yang menggerakkan diri karyawan yang terarah atau tertuju untuk mencapai tujuan organisasi perusahaan. Sikap mental karyawan yang pro dan positif terhadap situasi kerja itulah yang memperkuat motivasi kerjanya untuk mencapai kinerja maksimal.

Motivasi dapat merupakan serangkaian sikap dan nilai-nilai yang mempengaruhi individu untuk mencapai hal yang spesifik sesuai dengan tujuan individu. Sikap dan nilai tersebut merupakan suatu yang invisible yang memberikan kekuatan untuk mendorong individu bertingkah laku dalam mencapai tujuan (Rivai, 2005:455). 
Menurut Hasibuan (2008:202) motivasi kerja adalah sikap emosional yang menyenangkan dan mencintai pekerjaanya. Sikap ini dicerminkan oleh moral kerja, kedisiplinan, dan prestasi kerja. Sedangkan menurut Handoko dkk (2005:144) menyatakan bahwa motivasi kerja merupakan proses psikologis melalui keinginan yang belum terpuaskan yang diarahkan dan didorong ke pencapaian tujuan.

Motivasi juga dapat didefinisikan sebagai kesiapan khvusus seseorang untuk melakukan atau melanjutkan serangkaian aktivitas yang ditujukan untuk mencapai beberapa sasaran yang telah ditetapkan. Sedangkan motivasi kerja adalah sesuatu hal yang berasal dari internal individu yang menimbulkan dorongan atau semangat untuk bekerja keras (Ilyas, 2000:129).

Dari beberapa pendapat di atas dapat disimpulkan bahwa motivasi merupakan suatu dorongan yang timbul pada diri seseorang untuk mau mengerjakan sesuatu dalam upaya mewujudkan tujuan yang telah ditentukan sebelumnya. Jadi, hakekat dari motivasi itu adalah adanya semacam dorongan atau kekuatan yang menyebabkan seorang pegawai dengan kesadaran yang tinggi mau melaksanakan tugas dan tanggung jawab sebagaimana yang ditetapkan. dan motivasi harus dibangun dalam diri pegawai karena dengan ada motivasi dalam diri seorang maka akan memudahkan pimpinan mengarahkan pegawai kepada disiplin kerja yang baik.

\section{Peran Kepemimpinan Kepala Sekolah}

Robbins (2006:313) mendefinisikan peran sebagai seperangkat perilaku yang diharapkan dari seseorang yang menduduki posisi tertentu dalam unit sosial tertentu. Ada dua jenis perilaku yang diharapkan dalam suatu peran, yaitu (1) role perception: yaitu persepsi seseorang mengenai cara orang itu diharapkan berperilaku; atau dengan kata lain adalah pemahaman atau kesadaran mengenai pola perilaku atau fungsi yang diharapkan dari orang tersebut, dan (2) role expectation: yaitu cara orang lain menerima perilaku seseorang dalam situasi tertentu. Dengan peran yang dimainkan seseorang dalam organisasi, akan terbentuk suatu komponen penting dalam hal identitas dan kemampuan orang itu untuk bekerja.

Menurut Kohli et al (1998:264), peran kepemimpinan adalah keseluruhan usaha manajer/pimpinan yang berorientasi pada hasil yang diharapkan, aktivitas, dan kemampuan karyawannya untuk meningkatkan kinerja karyawan. Ini sebuah usaha untuk mempengaruhi kinerja dengan memastikan bahwa para pegawai melaksanakan tugasnya 
sesuai dengan standar, memiliki perangkat keahlian dan kemampuan yang dibutuhkan oleh pekerjaan, dan mendapatkan hasil yang diinginkan.

Dengan demikian peran kepemimpinan bisa dijelaskan sebagai seperangkat perilaku yang diharapkan dilaksanakan oleh pemimpin untuk mempengaruhi pegawai sehingga mereka mau berusaha secara sepenuh hati dan antusias untuk mencapai tujuan organisasi.

\section{METODE}

Berdasarkan kepada permasalahan yang akan diteliti, maka penelitian ini tergolong pada jenis penelitian deskriptif dan asosiatif. Melihat jumlah populasi yang cukup besar, maka pengambilan sampel dilakukan dengan teknik proporsional stratified random sampling, dimana sampel diambil secara acak, dan secara proporsional berdasarkan strata atau golongan/pangkat guru dari masing-masing sekolah yang diteliti. Untuk teknik pengumpulan data penelitian ini digunakan dengan metode angket dan dokumentasi. Teknik analisis data dalam penelitian ini yaitu analisis deskriptif dan analisis jalur.

\section{HASIL DAN PEMBAHASAN}

\section{HASIL PENELITIAN}

Analisis Deskriptif

Distribusi frekuensi disiplin kerja dengan indikator ketepatan waktu dapat diketahui rerata skor 4,13 dengan tingkat ketercapaian responden yaitu 82,67\%. Angka ini berada pada rentang 71\% - 85\% dapat dikatakan disiplin kerja guru pada indikator ketepatan waktu berkategori baik. Artinya bahwa guru sudah bekerja sesuai harapan, hadir di kelas sesuai jadual dan menjalankan tugasnya secara profesional.

Kemudian pada indikator menggunakan perlengkapan kantor/fasilitas sekolah dengan baik skor rata-rata 3,69 dengan tingkat ketercapaian responden sebesar 73,78\%. Angka ini berada pada rentang $71 \%$ - $85 \%$, berarti rata-rata guru mengunakan perlengkapan/fasilitas sekolah secara baik dapat dikategorikan baik. Begitu juga untuk indikator tanggung jawab yang tinggi tingkat ketercapaian responden sebesar 87,56\%. Angka ini berada pada rentang 86\% - 100\% berarti tanggungjawab yang dimiliki oleh guru pada kategori sangat baik. Selanjutnya untuk indikator ketaatan/patuh pada aturan 
yang telah ditentukan tingkat ketercapaian responden sebesar 84,89\%. Angka ini berada pada rentang 71\% - 85\%, artinya ketaatan/patuh pada aturan yang dimiliki oleh guru sudah pada dikategorikan baik. Tingkat ketercapaian responden untuk variabel disiplin kerja guru adalah 82,22\%, Hal ini bermakna bahwa secara rata-rata disiplin kerja guru SMKN 1 Depok dan SMKS Yapan Indonesia berkategori baik.

Tabel 1. Distribusi Frekuensi Disiplin Kerja

\begin{tabular}{|c|c|c|c|c|c|c|c|c|c|c|c|c|c|c|}
\hline \multirow[t]{2}{*}{ No. } & \multirow[t]{2}{*}{ Indikator } & \multicolumn{2}{|c|}{ Selalu } & \multicolumn{2}{|c|}{ Sering } & \multicolumn{2}{|c|}{$\begin{array}{l}\text { Kadang- } \\
\text { Kadang }\end{array}$} & \multicolumn{2}{|c|}{ Jarang } & \multicolumn{2}{|c|}{$\begin{array}{c}\text { Tidak } \\
\text { Perna } \\
\mathrm{h} \\
\end{array}$} & \multirow{2}{*}{$\begin{array}{c}\text { Rerata } \\
\begin{array}{c}\text { (mean } \\
\text { ) }\end{array}\end{array}$} & \multirow{2}{*}{$\begin{array}{r}\text { TCR } \\
(\%)\end{array}$} & \multirow[t]{2}{*}{ Ket. } \\
\hline & & $\mathrm{Fi}$ & $\%$ & $F i$ & $\%$ & $\mathrm{Fi}$ & $\%$ & $\begin{array}{l}F \\
i\end{array}$ & $\%$ & $\begin{array}{c}F \\
i\end{array}$ & $\%$ & & & \\
\hline 1 & Ketepatan waktu & $\begin{array}{l}3 \\
6\end{array}$ & $\begin{array}{c}40.0 \\
0\end{array}$ & $\begin{array}{l}3 \\
8\end{array}$ & $\begin{array}{c}42.2 \\
2\end{array}$ & 9 & $\begin{array}{c}10.0 \\
0\end{array}$ & 6 & 6.67 & 1 & $\begin{array}{c}1.2 \\
5\end{array}$ & 4.13 & $\begin{array}{c}82.6 \\
7\end{array}$ & Baik \\
\hline 2 & $\begin{array}{l}\text { Menggunakan } \\
\text { perlengkapan } \\
\text { kantor dengan } \\
\text { baik }\end{array}$ & $\begin{array}{l}1 \\
8\end{array}$ & $\begin{array}{c}20.0 \\
0\end{array}$ & $\begin{array}{l}3 \\
7\end{array}$ & $\begin{array}{c}41.1 \\
1\end{array}$ & $\begin{array}{l}2 \\
5\end{array}$ & $\begin{array}{c}27.7 \\
8\end{array}$ & 9 & $\begin{array}{c}10.0 \\
0\end{array}$ & 1 & $\begin{array}{c}1.1 \\
1\end{array}$ & 3.69 & $\begin{array}{c}73.7 \\
8\end{array}$ & Baik \\
\hline 3 & $\begin{array}{l}\text { Tanggungjawab } \\
\text { yang tinggi }\end{array}$ & $\begin{array}{l}4 \\
4\end{array}$ & $\begin{array}{c}48.8 \\
9\end{array}$ & $\begin{array}{l}3 \\
6\end{array}$ & $\begin{array}{c}40.0 \\
0\end{array}$ & $\begin{array}{l}1 \\
0\end{array}$ & $\begin{array}{c}11.1 \\
1\end{array}$ & 0 & 0.00 & 0 & $\begin{array}{c}0.0 \\
0\end{array}$ & 4.38 & $\begin{array}{c}87.5 \\
6\end{array}$ & $\begin{array}{l}\text { Sanga } \\
\text { t Baik }\end{array}$ \\
\hline 4 & $\begin{array}{l}\text { Ketaatan/patuh } \\
\text { terhadap aturan }\end{array}$ & $\begin{array}{l}4 \\
1\end{array}$ & $\begin{array}{c}45.5 \\
6 \\
\end{array}$ & $\begin{array}{l}3 \\
3 \\
\end{array}$ & $\begin{array}{c}36.6 \\
7 \\
\end{array}$ & $\begin{array}{l}1 \\
3 \\
\end{array}$ & $\begin{array}{c}14.4 \\
4\end{array}$ & 3 & 3.33 & 0 & $\begin{array}{c}0.0 \\
0\end{array}$ & 4.24 & $\begin{array}{c}84.8 \\
9\end{array}$ & Baik \\
\hline & Rerata Variabel & $\begin{array}{l}3 \\
5\end{array}$ & $\begin{array}{c}38.8 \\
9\end{array}$ & $\begin{array}{l}3 \\
6\end{array}$ & $\begin{array}{c}40.0 \\
0\end{array}$ & $\begin{array}{l}1 \\
4\end{array}$ & $\begin{array}{c}15.5 \\
6\end{array}$ & 4 & 4.44 & 1 & $\begin{array}{c}1.1 \\
1\end{array}$ & 4.11 & $\begin{array}{c}82.2 \\
2\end{array}$ & Baik \\
\hline
\end{tabular}

Sumber : Pengolahan Data Primer Tahun 2017

Pada tabel 2, yaitu ringkasan tabel distribusi frekuensi kepuasan kerja. Terlihat pada variabel kepuasan kerja dengan indikator kepuasan terhadap pekerjaan dapat diketahui skor rata-rata sebesar 4,16 tingkat ketercapaian responden yaitu 83,11\%. Angka ini berada pada rentang 71\% - 85\% dapat diartikan bahwa kepuasan terhadap pekerjaan pada diri guru dikategorikan baik.

Selanjutnya pada indikator kepuasan terhadap promosi dapat diketahui skor rerata sebesar 4,01 dengan tingkat ketercapaian responden sebesar 80,22\%. Angka ini berada pada rentang 71\% - 85\% dapat diartikan bahwa pada umumnya guru merasa puas dengan promosi jabatan atau dengan kata lain penghargaan terhadap guru.

Sedangkan pada indikator kepuasan terhadap rekan kerja skor rata-rata sebesar 4,13 yaitu. Jika dilihat dari skor rata-rata untuk tingkat ketercapaian responden sebesar 82,67\%. Angka ini berada pada rentang 71\% - 85\%, dikategorikan baik. Maknanya bahwa rata-rata guru merasa puas dengan rekan kerja, mereka mampu bekerja secara team work, terjalin suasana kerja yang kondusif. Kemudian mengenai kepuasan kerja pada indikator 
kepuasan terhadap manajemen, rerata skor sebesar 3,94 dengan tingkat capaian responden 78,89\%. Angka ini berada pada rentang 71\% - 85\% berkategori baik. Hal ini bermakna bahwa kepuasan kerja guru mengenai manajemen sekolah sudah cukup baik. Guru merasa puas dengan sistem manajemen di sekolah tempat mereka mengajar.

Tingkat ketercapaian responden untuk variabel kepuasan kerja guru SMKN 1 Depok dan SMKS Yapan Indonesia adalah 81,11\%, hal ini bermakna bahwa kepuasan kerja guru dikatakan baik, karena pada rentang 71\% - 85\%.

\section{Tabel 2. Distribusi Frekuensi Kepuasan Kerja}

\begin{tabular}{|c|c|c|c|c|c|c|c|c|c|c|c|c|c|c|}
\hline \multirow{2}{*}{ No. } & \multirow{2}{*}{ Indikator } & \multicolumn{2}{|c|}{$\begin{array}{c}\text { Sangat } \\
\text { Puas }\end{array}$} & \multicolumn{2}{|c|}{ Puas } & \multicolumn{2}{|c|}{$\begin{array}{c}\text { Biasa } \\
\text { Saja }\end{array}$} & \multicolumn{2}{|c|}{$\begin{array}{c}\text { Kurang } \\
\text { Puas }\end{array}$} & \multicolumn{2}{|c|}{$\begin{array}{l}\text { Tidak } \\
\text { Puas }\end{array}$} & \multirow{2}{*}{$\begin{array}{c}\text { Rerata } \\
\text { (mean } \\
\text { ) }\end{array}$} & \multirow{2}{*}{$\begin{array}{r}\text { TCR } \\
(\%)\end{array}$} & \multirow[t]{2}{*}{ Ket. } \\
\hline & & $\mathrm{Fi}$ & $\%$ & $\mathrm{Fi}$ & $\%$ & $\mathrm{Fi}$ & $\%$ & $\begin{array}{l}F \\
i\end{array}$ & $\%$ & $\begin{array}{l}F \\
i\end{array}$ & $\%$ & & & \\
\hline 1 & $\begin{array}{l}\text { Kepuasan } \\
\text { terhadap } \\
\text { pekerjaan }\end{array}$ & $\begin{array}{l}3 \\
2\end{array}$ & $\begin{array}{c}35.5 \\
6\end{array}$ & $\begin{array}{l}4 \\
1\end{array}$ & $\begin{array}{c}45.5 \\
6\end{array}$ & $\begin{array}{l}1 \\
6\end{array}$ & $\begin{array}{c}17.7 \\
8\end{array}$ & 1 & 1.11 & 0 & $\begin{array}{c}0.0 \\
0\end{array}$ & 4.16 & $\begin{array}{c}83.1 \\
1\end{array}$ & Baik \\
\hline 2 & $\begin{array}{l}\text { Kepuasan } \\
\text { terhadap promosi }\end{array}$ & $\begin{array}{l}3 \\
4\end{array}$ & $\begin{array}{c}37.7 \\
8\end{array}$ & $\begin{array}{l}3 \\
2\end{array}$ & $\begin{array}{c}35.5 \\
6\end{array}$ & $\begin{array}{l}1 \\
5\end{array}$ & $\begin{array}{c}16.6 \\
7\end{array}$ & 9 & $\begin{array}{c}10.0 \\
0\end{array}$ & 0 & $\begin{array}{c}0.0 \\
0\end{array}$ & 4.01 & $\begin{array}{c}80.2 \\
2\end{array}$ & Baik \\
\hline 3 & $\begin{array}{l}\text { Kepuasan } \\
\text { terhadap rekan } \\
\text { kerja }\end{array}$ & $\begin{array}{l}3 \\
5\end{array}$ & $\begin{array}{c}38.8 \\
9\end{array}$ & $\begin{array}{l}3 \\
7\end{array}$ & $\begin{array}{c}41.1 \\
1\end{array}$ & $\begin{array}{l}1 \\
3\end{array}$ & $\begin{array}{c}14.4 \\
4\end{array}$ & 5 & 5.56 & 0 & $\begin{array}{c}0.0 \\
0\end{array}$ & 4.13 & $\begin{array}{c}82.6 \\
7\end{array}$ & Baik \\
\hline 4 & $\begin{array}{l}\text { Kepuasan } \\
\text { terhadap } \\
\text { manajemen }\end{array}$ & $\begin{array}{l}2 \\
5\end{array}$ & $\begin{array}{c}27.7 \\
8\end{array}$ & $\begin{array}{l}3 \\
7\end{array}$ & $\begin{array}{c}41.1 \\
1\end{array}$ & $\begin{array}{l}2 \\
6\end{array}$ & $\begin{array}{c}28.8 \\
9\end{array}$ & 2 & 2.22 & 0 & $\begin{array}{c}0.0 \\
0\end{array}$ & 3.94 & $\begin{array}{c}78.8 \\
9\end{array}$ & Baik \\
\hline & Rerata Variabel & $\begin{array}{l}3 \\
1 \\
\end{array}$ & $\begin{array}{c}34.4 \\
4 \\
\end{array}$ & $\begin{array}{l}3 \\
7 \\
\end{array}$ & $\begin{array}{c}41.1 \\
1\end{array}$ & $\begin{array}{l}1 \\
8 \\
\end{array}$ & $\begin{array}{c}20.0 \\
0 \\
\end{array}$ & 4 & 4.44 & 0 & $\begin{array}{c}0.0 \\
0\end{array}$ & 4.06 & $\begin{array}{c}81.1 \\
1\end{array}$ & Baik \\
\hline
\end{tabular}

Sumber : Pengolahan Data Primer Tahun 2017

Tabel 3. Distribusi Frekuensi Motivasi Kerja

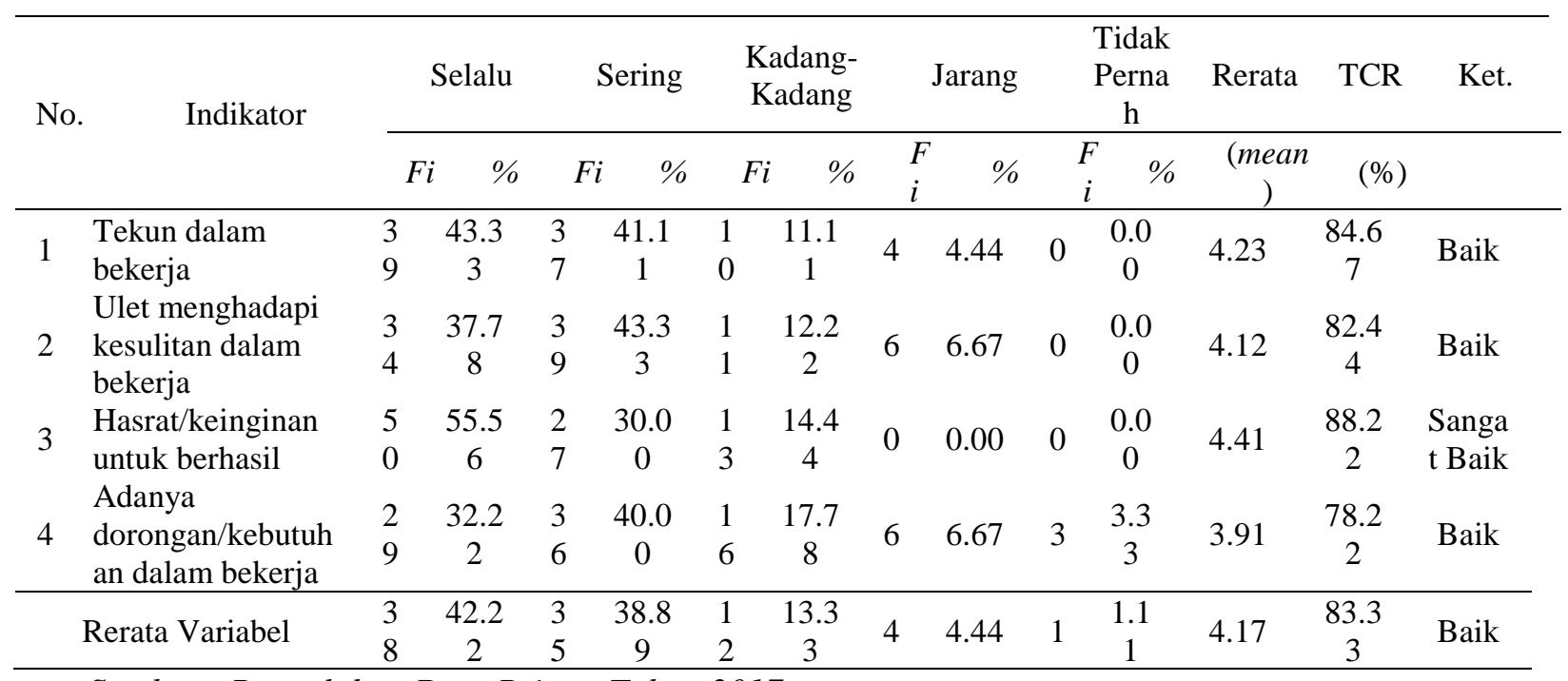

Sumber : Pengolahan Data Primer Tahun 2017 
Dari hasil olahan data, pada tabel 3 di atas, dapat dilihat bahwa pada indikator tekun dalam bekerja dapat diketahui skor rata-rata 4,23 dengan tingkat ketercapaian responden yaitu 84,67\%. Angka ini berada pada rentang 71\% - 85\%, artinya motivasi kerja guru pada indikator tekun dalam bekerja dikategorikan baik atau dapat dikatakan guru memiliki ketekunan yang cukup baik.

Kemudian pada indikator ulet menghadapi kesulitan dalam bekerja dapat diketahui skor rerata yaitu 4,12. Tingkat ketercapaian responden sebesar 82,44\%. Angka ini berada pada rentang 71\% - 85\% yang berarti bahwa pada umumnya guru mampu menhadapi masalah dan mampu menyelesaikan masalah. Selanjutnya pada indikator hasrat/keinginan untuk berhasil dapat diketahui skor rerata sebesar 4,41 Tingkat ketercapaian responden pada indikator keinginan untuk berhasil sebesar 88,22\%. Angka ini berada pada rentang $86 \%$ - $100 \%$, Artinya bahwa rata-rata guru memiliki hasrat yang sangat tinggi untuk berhasil dalam pekerjaannya, dalam usahanya untuk mencerdaskan peserta didiknya.

Selanjutnya motivasi kerja guru pada indikator adanya kebutuhan/dorongan dalam bekerja dapat diketahui skor rerata sebesar 3,91 dengan tingkat ketercapaian responden sebesar 78,22\%. Angka ini berada pada rentang 71\% - 85\% yang berarti bahwa guru memiliki dorongan/kebutuhan yang cukup kuat atau cukup baik dalam bekerja/mengajar. Mereka menyadari dengan baik segala sesuatu yang dibutuhkan agar proses belajar mengajar berjalan dengan lancer, peserta didik merasa terpuaskan dan terbangun suasana belajar yang menyenangkan.

Tingkat ketercapaian responden dari masing-masing indikator untuk variabel fasilitas belajar di rumah, dapat diketahui rerata variabelnya yaitu sebesar 83,33\%. Angka ini berada pada rentang 71\% - 85\% yang berarti motivasi kerja guru SMKN 1 Depok dan SMKS Yapan Indonesia pada kategori baik.

Tabel 4. Distribusi Frekuensi Peran Kepemimpinan Kepala Sekolah

\begin{tabular}{|c|c|c|c|c|c|c|c|c|c|c|c|c|c|c|}
\hline \multirow[t]{2}{*}{ No. } & \multirow[t]{2}{*}{ Indikator } & \multicolumn{2}{|c|}{ Selalu } & \multicolumn{2}{|c|}{ Sering } & \multicolumn{2}{|c|}{$\begin{array}{l}\text { Kadang- } \\
\text { Kadang }\end{array}$} & \multicolumn{2}{|c|}{ Jarang } & \multicolumn{2}{|c|}{$\begin{array}{c}\text { Tidak } \\
\text { Perna } \\
\text { h }\end{array}$} & \multirow{2}{*}{$\begin{array}{c}\text { Rerata } \\
\begin{array}{c}\text { mean } \\
\text { ) }\end{array} \\
\end{array}$} & \multirow{2}{*}{$\begin{array}{r}\text { TCR } \\
(\%)\end{array}$} & \multirow[t]{2}{*}{ Ket. } \\
\hline & & $F i$ & $\%$ & $F i$ & $\%$ & $F i$ & $\%$ & $\begin{array}{l}F \\
i\end{array}$ & $\%$ & $\begin{array}{c}F \\
i\end{array}$ & $\%$ & & & \\
\hline 1 & $\begin{array}{l}\text { Kepala sekolah } \\
\text { sebagai pemberi } \\
\text { visi dan strategi }\end{array}$ & $\begin{array}{l}2 \\
9\end{array}$ & $\begin{array}{c}32.2 \\
2\end{array}$ & $\begin{array}{l}4 \\
7\end{array}$ & $\begin{array}{c}52.2 \\
2\end{array}$ & $\begin{array}{l}1 \\
4\end{array}$ & $\begin{array}{c}15.5 \\
6\end{array}$ & 0 & 0.00 & 0 & $\begin{array}{c}0.0 \\
0\end{array}$ & 4.17 & $\begin{array}{c}83.3 \\
3\end{array}$ & Baik \\
\hline 2 & $\begin{array}{l}\text { Kepala sekolah } \\
\text { sebagai pelatih }\end{array}$ & $\begin{array}{l}3 \\
8\end{array}$ & $\begin{array}{c}42.2 \\
2\end{array}$ & $\begin{array}{l}4 \\
2\end{array}$ & $\begin{array}{c}46.6 \\
7\end{array}$ & $\begin{array}{l}1 \\
0\end{array}$ & $\begin{array}{c}11.1 \\
1\end{array}$ & 0 & 0.00 & 0 & $\begin{array}{c}0.0 \\
0\end{array}$ & 4.31 & $\begin{array}{c}86.2 \\
2\end{array}$ & $\begin{array}{l}\text { Sanga } \\
\text { t Baik }\end{array}$ \\
\hline
\end{tabular}




\begin{tabular}{|c|c|c|c|c|c|c|c|c|c|c|c|c|c|c|}
\hline 3 & $\begin{array}{l}\text { Kepala sekolah } \\
\text { sebagai agen } \\
\text { perubahan }\end{array}$ & $\begin{array}{l}4 \\
7\end{array}$ & $\begin{array}{c}52.2 \\
2\end{array}$ & $\begin{array}{l}3 \\
1\end{array}$ & $\begin{array}{c}34.4 \\
4\end{array}$ & 8 & 8.89 & 4 & 4.44 & 0 & $\begin{array}{c}0.0 \\
0\end{array}$ & 4.34 & $\begin{array}{c}86.8 \\
9\end{array}$ & $\begin{array}{l}\text { Sanga } \\
\text { t Baik }\end{array}$ \\
\hline 4 & $\begin{array}{l}\text { Kepala sekolah } \\
\text { sbg pengontrol } \\
\text { hasil, aktivitas } \\
\text { dan } \\
\text { kemampuan } \\
\text { pegawai }\end{array}$ & $\begin{array}{l}3 \\
5\end{array}$ & $\begin{array}{c}38.8 \\
9\end{array}$ & $\begin{array}{l}3 \\
9\end{array}$ & $\begin{array}{c}43.3 \\
3\end{array}$ & $\begin{array}{l}1 \\
5\end{array}$ & $\begin{array}{c}16.6 \\
7\end{array}$ & 1 & 1.11 & 0 & $\begin{array}{c}0.0 \\
0\end{array}$ & 4.20 & $\begin{array}{c}84.0 \\
0\end{array}$ & Baik \\
\hline & erata Variabel & $\begin{array}{l}3 \\
7\end{array}$ & $\begin{array}{c}41.1 \\
1\end{array}$ & $\begin{array}{l}4 \\
0\end{array}$ & $\begin{array}{c}44.4 \\
4\end{array}$ & $\begin{array}{l}1 \\
2\end{array}$ & $\begin{array}{c}13.3 \\
3\end{array}$ & 1 & 1.11 & 0 & $\begin{array}{c}0.0 \\
0\end{array}$ & 4.26 & $\begin{array}{c}85.1 \\
1\end{array}$ & Baik \\
\hline
\end{tabular}

Sumber : Pengolahan Data Primer Tahun 2017

Pada tabel 4, distribusi frekuensi peran kepemimpinan kepala sekolah. Terlihat pada indikator Kepala sekolah sebagai pemberi visi dan strategi diketahui skor rata-rata sebesar 4,17 tingkat ketercapaian responden sebesar 83,33 \%. Angka ini berada pada rentang 71\% - 85\% dapat diartikan bahwa peran kepala sekolah sebagai pemberi visi dan strategi cukup baik. Selanjutnya pada indikator Kepala sekolah sebagai pelatih dapat diketahui skor rerata sebesar 4,31 dengan tingkat ketercapaian responden untuk indikator peran konsultatif sebesar 86,22\%. Angka ini berada pada rentang 86\% - 100\% dapat diartikan bahwa kepala sekolah mampu bertindak dengan sangat baik sebagai pelatih, konsultan, memberikan arahan-arahan yang konstruktif kepada guru dalam menjalankan tugasnya.

Selanjutnya, indikator Kepala sekolah sebagai agen perubahan tingkat ketercapaian responden sebesar 86,89\%. Angka ini berada pada rentang 86\% - 100\%, artinya bahwa rata-rata peran kepala sekolah sebagai agen perubahan dikatakan sangat baik. Kemudian untuk indikator pengontrol hasil, aktivitas dan kemampuan pegawai. skor rata-rata yaitu sebesar 4,20. Jika dilihat dari tingkat ketercapaian responden untuk indikator tersebut sebesar 84,00\%. Angka ini berada pada rentang 71\% - 85\%, artinya bahwa peran kepala sekolah sebagai pengontrol hasil, aktivitas dan kemampuan pegawai dikatakan baik. Peran kepemimpinan kepala sekolah dapat diketahui tingkat capaian responden sebesar 85,11 \%, hal ini bermakna bahwa peran kepemimpinan oleh kepala sekolah dapat dikatakan sudah baik.

\section{Analisis Induktif}

\section{Uji Hipotesis}

Berdasarkan pengujian hipotesis, dapat dilihat pengaruh langsung dan tidak langsung variabel independen melalui variabel intervening terhadap variabel dependen sebagai berikut: 


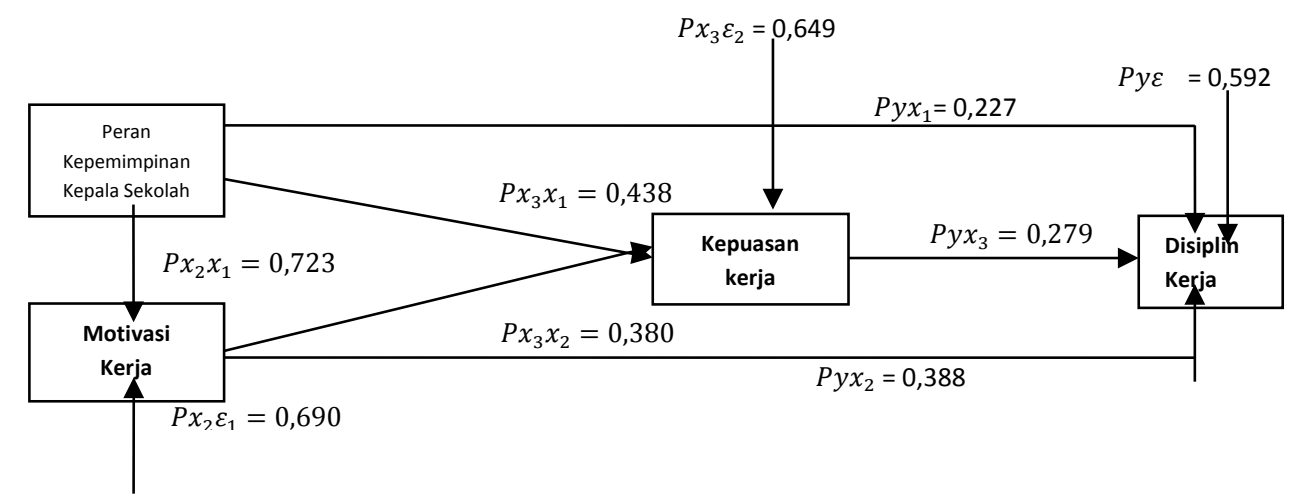

Gambar 1. Pengaruh Langsung dan Tidak Langsung antara Variabel Bebas terhadap

\section{Variabel Terikat}

Pada tabel berikut ini dapat dilihat secara jelas pengaruh langsung dan pengaruh tidak langsung antara variabel sebab dan variabel akibat:

Tabel 5. Tabel Pengaruh Langsung dan Pengaruh Tidak Langsung

\begin{tabular}{|c|c|c|c|c|}
\hline \multirow[b]{2}{*}{ No. } & \multirow[b]{2}{*}{ Variabel } & \multicolumn{3}{|c|}{ Pengaruh } \\
\hline & & $\begin{array}{c}\text { Tindak } \\
\text { Langsung }\end{array}$ & $\begin{array}{c}\text { Langsun } \\
\text { g }\end{array}$ & $\begin{array}{c}\text { Total } \\
(\%)\end{array}$ \\
\hline 1. & $\mathrm{X}_{1}$ terhadap Y & - & 0,0515 & 5,15 \\
\hline 2. & $\mathrm{X}_{1}$ terhadap Y melalui $\mathrm{X}_{2}$ & 0,0636 & - & 6,36 \\
\hline 3. & $\mathrm{X}_{1}$ terhadap Y melalui $\mathrm{X}_{3}$ & 0,0277 & - & 2,77 \\
\hline 4. & $\mathrm{X}_{2}$ terhadap $\mathrm{Y}$ & - & 0,1505 & 15,05 \\
\hline 5. & $\mathrm{X}_{2}$ terhadap Y melalui $\mathrm{X}_{3}$ & 0,0411 & - & 4,11 \\
\hline 6. & $\mathrm{X}_{3}$ terhadap $\mathrm{Y}$ & - & 0,0778 & 7,78 \\
\hline 7. & Pengaruh variabel lain & - & - & 59,20 \\
\hline \multicolumn{4}{|c|}{ Total Keseluruhan } & 100 \\
\hline
\end{tabular}

Sumber : Pengolahan Data Primer Tahun 2017

\section{Hipotesis Pertama}

di peroleh thitung $=9,822$, sedangkan $t$ tabel $=1,988$. Hal ini menunjukkan bahwa $t_{\text {hit }}>t_{t a b}(9,822>1,988)$, maka dapat disimpulkan hipotesis $\mathrm{H}_{0}$ ditolak. Artinya Peran Kepemimpinan berpengaruh signifikan terhadap Motivasi Kerja.

\section{Hipotesis Kedua}

Diperoleh thitung $=4,346$ sedangkan $\mathrm{t}$ tabel $=1,988$. Hal ini menunjukkan bahwa $t_{\text {hit }}>t_{t a b}(4,346>1,988)$, maka dapat disimpulkan bahwa hipotesis $\mathrm{H}_{0}$ ditolak. Artinya Peran Kepemimpinan Kepala Sekolah berpengaruh signifikan terhadap Kepuasan Kerja. 


\section{Hipotesis Ketiga}

Diperoleh thitung $=2,228$ sedangkan $t$ tabel $=1,988$. Hal ini menunjukkan bahwa $t_{\text {hit }}>t_{t a b}(2,228>1,988)$, maka dapat disimpulkan bahwa Hipotesis $\mathrm{H}_{0}$ ditolak. Artinya Peran Kepemimpinan Kepala Sekolah berpengaruh signifikan terhadap Disiplin Kerja.

\section{Hipotesis Keempat}

Diperoleh thitung $=3,771$ sedangkan $t$ tabel $=1,988$. Hal ini menunjukkan bahwa $t_{\text {hit }}>t_{\text {tab }}(3,771>1,988)$, maka dapat disimpulkan bahwa hipotesis $\mathrm{H}_{0}$ ditolak. Artinya Motivasi Kerja berpengaruh signifikan terhadap Kepuasan Kerja.

\section{Hipotesis Kelima}

Diperoleh t hitung $=3,891$, sedangkan $\mathrm{t}$ tabel $=1,988$. Hal ini menunjukkan bahwa $t_{\text {hit }}>t_{t a b}(3,891>1,988)$, maka dapat disimpulkan bahwa hipotesis $\mathrm{H}_{0}$ ditolak. Artinya Motivasi Kerja berpengaruh signifikan terhadap Disiplin Kerja guru.

\section{Hipotesis Keenam}

Diperoleh t hitung $=2,834$, sedangkan t tabel $=1$,988. Hal ini menunjukkan bahwa $t_{\text {hit }}>t_{t a b}(2,834>1,988)$, maka dapat disimpulkan bahwa hipotesis $\mathrm{H}_{0}$ ditolak. Artinya Kepuasan Kerja berpengaruh signifikan terhadap Disiplin Kerja.

\section{PEMBAHASAN}

1. Pengaruh Peran Kepemimpinan Kepala Sekolah terhadap Motivasi Kerja Guru SMKN 1 Depok dan SMKS Yapan Indonesia

Berdasarkan pengujian hipotesis, terdapat pengaruh positif signifikan Peran Kepemimpinan Kepala Sekolah terhadap Motivasi Kerja Guru SMKN 1 Depok dan SMKS Yapan Indonesia. Artinya apabila peran kepemimpinan kepala sekolah baik, dalam hal ini kepala sekolah mampu menggerakkan dan memberdayakan guru secara baik maka akan semakin baik motivasi kerja guru. Sebaliknya, apabila peran kepemimpinan kepala sekolah kurang baik atau bahkan tidak efektif, tidak berwibawa karena kepala sekolah tidak menjalankan fungsinya sebagai pemimpin, maka motivasi kerja pada guru pun akan semakin buruk.

Hasil penelitian ini didukung oleh Wahyuningsih, Binarsih dan Istiatin (2013) yang menyatakan bahwa Peran kepemimpinan berpengaruh positif signifikan terhadap motivasi kerja pegawai Badan Kepegawaian Daerah Kota Surakarta. Kemudian oleh Gede Prawira dan Made Subudi (2013) yang menyatakan bahwa Peran kepemimpinan 
berpengaruh signifikan terhadap motivasi kereja karyawan Hotel Matahari Terbit Bali Tanjung Benoa-Nusa Dua

2. Pengaruh Peran Kepemimpinan Kepala Sekolah terhadap Kepuasan Kerja Guru SMKN 1 Depok dan SMKS Yapan Indonesia

Berdasarkan pengujian hipotesis diperoleh bahwa Peran Kepemimpinan berpengaruh positif signifikan terhadap Kepuasan Kerja Guru SMKN 1 Depok dan SMKS Yapan Indonesia, artinya ketika peran kepemimpinan kepala sekolah sesuai harapan guru dan karyawan maka semakin meningkat kepuasan kerja guru. Sebaliknya, Peran atau pola Kepemimpinan Kepala Sekolah tidak baik, kepala sekolah tidak menjadi dirinya sebagai figur yang harus dicontoh oleh bawahannya maka kepuasan kerja pada diri guru cenderung akan semakin menurun karena guru merasa kurang cocok dengan sikap pemimpin yang arrogant, kurang perhatian terhadap permasalahan yang dihadapi bawahannya, sehingga kepuasan kerja menurun.

Sebagaimana dikemukakan Handoko (1995) menyatakan bahwa Peran kepemimpinan adalah bagaimana seorang pemimpin dapat dengan tepat mengarahkan tujuan perseorangan dan tujuan organisasi. Sedangkan kepuasan kerja merupakan sikap umum seorang individu terhadap pekerjaanya. Semakin banyak aspek yang sesuai dengan keinginan individu tersebut maka semakin tinggi kepuasan kerjanya (Wexley dan Yulk, 1992 dalam Waridin dan Masrukhin, 2006). Dari dua pengertian tentang Peran kepemimpinan dan kepuasan kerja dapat ditarik suatu kesimpulan bahwa apabila Peran kepemimpinan yang diterapkan dapat dengan tepat mengarahkan tujuan organisasi dengan aspek-aspek / tujuan yang diharapkan individu atas pekerjaannya maka semakin tinggi kepuasan kerjanya. Hal ini didukung oleh penelitian yang dilakukan oleh Glisson dan Durick (1988) bahwa Peran kepemimpinan merupakan prediktor bagi kepuasan kerja dan komitmen organisasional.

3. Pengaruh Peran Kepemimpinan Kepala Sekolah terhadap Disiplin Kerja Guru SMKN 1 Depok dan SMKS Yapan Indonesia

Berdasarkan pengujian hipotesis, diperoleh bahwa Peran Kepemimpinan Kepala Sekolah berpengaruh positif signifikan terhadap Disiplin Kerja Guru. Dari hasil analisis dapat diketahui pengaruh langsung peran kepemimpinan terhadap disiplin kerja guru lebih besar pengaruhnya yaitu sebesar 5,15\% dibanding pengaruh tidak langsung melalui kepuasan kerja yaitu sebesar 2,77\%. Hal ini dikarenakan hasil 
analisis deskriptif menunjukkan peran kepemimpinan kepala sekolah lebih besar TCRnya yaitu 85,11\%. Sementara kepuasan kerja yaitu 81,11\%. Oleh karena itu fungsi kepuasan kerja hanya sebagai moderating variable. Namun, pengaruh tidak langsung peran kepemimpinan melalui motivasi kerja, lebih besar pengaruhnya yaitu 6,36\%. Sehingga fungsi motivasi kerja sebagai intervening variable.

Dari paparan tersebut, dapat disimpulkan maknanya yaitu bahwa untuk meningkatkan disiplin kerja, bukan hanya peran kepemimpinan saja yang perlu ditingkatkan. Akan tetapi terlebih dahulu harus meningkatkan motivasi kerja serta kepuasan kerja perlu ditingkatkan pada diri guru. Baik pengaruh langsung atau tidak langsung peran kepemimpinan kepala sekolah terhadap disiplin kerja, hasil uji hipotesis menunjukkan terdapat pengaruh positif signifikan Peran Kepemimpinan Kepala Sekolah terhadap Disiplin Kerja Guru SMKN 1 Depok dan SMKS Yapan Indonesia. Hal ini dapat diartikan bahwa peran kepemimpinan kepala sekolah yang ideal dalam hal ini kepala sekolah mampu menjadi contoh yang baik, cenderung meningkatkan disiplin kerja guru. Sebaliknya jika peran kepemimpinan kurang baik, maka akan mengakibatkan guru cenderung bersikap malas-malasan, kurang optimal dalam mengajar sehingga kualitas pendidikan pun akhirnya banyak dipertanyakan. Hal ini karena guru kurang puas dengan kebijakan pemimpin dan kurang termotivasi dalam mengajar, sehingga otomatis disiplin kerja guru cenderung mengalami penurunan.

Menurut Luthans (2003:26) mengemukakan beberapa faktor yang mempengaruhi disiplin kerja yakni kepemimpinan, gaji, promosi, supervisi, kelompok Kerja, motivasi Kerja. Lebih lanjut menurut Saydam (2000:286) faktor yang mempengaruhi tegak atau tidaknya disiplin dalam suatu organisasi antara lain ada atau tidak supervisi dari pimpinan, lingkungan kerja yang kondusif, motivasi kerja dari pegawai, kepuasan kerja, keberanian dan kemampuan pimpinan dalam mengambil tindakan dan ada atau tidaknya perhatian kepada para pegawai oleh atasan atau pemimpinnya.

4. Pengaruh Motivasi Kerja terhadap Kepuasan Kerja Guru SMKN 1 Depok dan SMKS Yapan Indonesia

Berdasarkan pengujian hipotesis diperoleh bahwa Motivasi Kerja berpengaruh positif signifikan terhadap Kepuasan Kerja Guru SMKN 1 Depok dan SMKS Yapan Indonesia. Artinya apabila motivasi kerja guru meningkat, maka akan meningkat pula 
kepuasan guru. Sebaliknya, apabila motivasi Kerja menurun, maka kepuasan kerja pun akan menurun. Motivasi kerja yang tinggi, cenderung berpengaruh baik terhadap pekerjaan. Proses pekerjaan dan hasil pekerjaan yang baik cenderung akan menimbulkan kepuasan kerja bagi guru.

Menurut Gomes (2009:177) menyatakan motivasi berkaitan erat dengan keberhasilan perusahaan dalam mencapai tujuan. Menurut Jugde et al (2001) harapan berbasis teori motivasi secara umum menetapkan bahwa kepuasan mengikuti dari manfaat yang dihasilkan kinerja. Gomes (2009:182) mengungkapkan adanya dua teori yang berhubungan dengan kepuasan kerja yaitu teori keadilan dan diskrepensi, teori ini menghubungkan kepuasan dengan rewards yang diterima. Penjelasan mengenai teori keadilan akan membantu seseorang untuk mengetahui perlakuan yang telah diterima sudah secara adil atau tidak, sedangkan teori diskrepensi membantu menentukan apa yang seharusnya diterima dengan kenyataan yang dia terima.

5. Pengaruh Motivasi Kerja terhadap Disiplin Kerja Guru SMKN 1 Depok dan SMKS Yapan Indonesia

Berdasarkan pengujian hipotesis diperoleh bahwa Motivasi Kerja berpengaruh positif signifikan terhadap Disiplin Kerja . Dari hasil analisis dapat diketahui pengaruh langsung motivasi kerja terhadap disiplin kerja lebih besar pengaruhnya yaitu sebesar 15,05\% dibanding pengaruh tidak langsung melalui kepuasan kerja yaitu hanya 4,11\%. Hal ini dikarenakan hasil analisis deskriptif menunjukkan motivasi kerja lebih besar TCRnya yaitu 83,33\%. Sementara kepuasan kerja hanya 81,11\%. Oleh karena itu fungsi kepuasan kerja hanya sebagai moderating variable.

Dari paparan tersebut, dapat disimpulkan maknanya yaitu bahwa untuk meningkatkan disiplin kerja guru, bukan hanya motivasi kerja saja yang perlu ditingkatkan. Akan tetapi harus meningkatkan kepuasan kerja.

Menurut Teori Dua Faktor (Two-Factor Theory) yang dikemukakan oleh Herzberg merupakan kerangka kerja lain untuk memahami implikasi motivasional dari lingkungan kerja dan ada dua faktor didalam teori ini yaitu : faktor-faktor higienis (sumber ketidakpuasan karyawan) dan faktor-faktor pemuas (sumber kepuasan karyawan) dalam teorinya Herzberg menyakini bahwa kepuasan kerja memotivasi pada kineija yang lebih baik. Faktor higienis seperti kebijakan perusahaan, supervisi dan gaji dapat menghilangkan ketidakpuasan. Faktor ini berhubungan erat dengan 
kontek pekerjaan. Perbaikan kontek pekerjaan tidak mengarah pada kepuasan yang lebih besar, tetapi diharapkan akan mengurangi ketidakpuasan. Di lain pihak, motivator atau pemuas seperti pencapaian, tanggung jawab dan penghargaan mendukung pada kepuasan kerja. Motivator berhubungan erat dengan kerja itu sendiri atau hasil langsung yang diakibatkannya, seperti peluang promosi, peluang pertumbuhan personal, pengakuan tanggung jawab dan prestasi. Perbaikan dalam isi pekerjaan mendorong pada peningkatan kepuasan dan motivasi untuk bekerja lebih baik.

Berdasarkan rumusan ini dapat dipahami bahwa disiplin seseorang sama dengan cermin kemampuan dan motivasi yang dimiliki. Seorang guru yang memiliki kemampuan mengajar namun tidak disertai dengan motivasi maka tidak akan mencapai hasil kerja yang baik. Sebaliknya, seorang guru yang memiliki motivasi tinggi untuk mengajar namun tidak disertai dengan kemampuan mengajar dengan baik tidaklah mungkin mencapai hasil kerja dengan baik. Oleh karena itu tercapai atau tidaknya suatu pekerjaan tergantung dari tingkat kemampuan dan motivasi yang dimiliki oleh guru. tautan antara kemampuan dan motivasi akan menghasilkan kinerja sebagaimana yang diharapkan.

6. Pengaruh Kepuasan Kerja terhadap Disiplin Kerja Guru SMKN 1 Depok dan SMKS Yapan Indonesia

Berdasarkan pengujian hipotesis diperoleh bahwa Kepuasan Kerja berpengaruh positif signifikan terhadap Disiplin Kerja Guru SMKN 1 Depok dan SMKS Yapan Indonesia. Artinya apabila kepuasan kerja guru meningkat, maka akan meningkatkan disiplin kerja guru. Sebaliknya, apabila guru tidak puas dalam bekerja, tidak nyaman dengan suasana kerja, kurang puas dengan promosi atasan yang kurang adil, maka secara otomatis disiplin kerja cenderung akan menurun.

Jurnal Agustina dan Sulaiman (2013) menunjukkan bahwa terdapat pengaruh yang positif dan signifikan kepuasan kerja terhadap disiplin kerja guru SMA Negeri di Kabupaten Pidie.

Kepuasan kerja guru, merupakan tingkat pemenuhan kebutuhan harapanharapan sehingga akan menimbulkan rasa senang atau tidaknya guru dalam menjalankan tugas dan pencapaian tujuan pembelajaran. Karena itu kepuasan kerja guru, berkaitan dengan psikologis. Rasa puasnya guru dalam melaksanakan tugas, 
berbeda antara guru yang satu dengan guru yang lain. Jadi kepuasan kerja guru merupakan suatu hal yang relatif, dan sukar untuk mengukur psikologi seseorang. Sejalan dengan pengertian ini Robbins (2009:90) mengatakan bahwa "Guru dalam menjalankan tugasnya menanggung berbagai beban psikologis, baik yang berhubungan dengan perilaku peserta didik, tingkat kedalaman kurikulum yang tidak seimbang dengan kemampuannya”. Oleh karena itu yang kurang puas, atau terbebani secara psikologis maka guru cenderung kurang disiplin dalam proses belajar mengajar.

\section{SIMPULAN DAN SARAN}

\section{SIMPULAN}

1. Peran kepemimpinan kepala sekolah berpengaruh positif signifikan terhadap motivasi kerja guru SMKN 1 Depok dan SMKS Yapan Indonesia. Artinya apabila peran kepemimpinan kepala sekolah baik, dalam hal ini kepala sekolah mampu menggerakkan dan memberdayakan guru secara baik maka akan semakin baik motivasi kerja guru. Sebaliknya, apabila peran kepemimpinan kepala sekolah kurang efektif, kurang berwibawa karena kepala sekolah tidak menjalankan fungsinya sebagai pemimpin, maka motivasi kerja pada guru pun akan semakin buruk.

2. Peran kepemimpinan kepala sekolah berpengaruh positif signifikan terhadap kepuasan kerja guru SMKN 1 Depok dan SMKS Yapan Indonesia. Artinya apabila peran kepemimpinan kepala sekolah baik atau pola kepemimpinan kepala sekolah sesuai harapan guru dan karyawan maka semakin meningkat kepuasan kerja guru. Sebaliknya, Peran atau pola kepemimpinan kepala sekolah tidak baik, kepala sekolah tidak menjadi dirinya sebagai figur yang harus dicontoh oleh bawahannya maka kepuasan kerja pada diri guru cenderung akan semakin menurun karena guru merasa kurang cocok dengan sikap pemimpin yang arrogant, kurang perhatian terhadap permasalahan yang dihadapi bawahannya, sehingga kepuasan kerja menurun.

3. Peran kepemimpinan kepala sekolah berpengaruh positif signifikan terhadap disiplin kerja, baik secara langsung maupun tidak langsung Artinya bahwa peran kepemimpinan kepala sekolah yang ideal dalam hal ini kepala sekolah mampu menjadi contoh yang baik, cenderung meningkatkan disiplin kerja guru. Sebaliknya jika peran kepemimpinan kurang baik, maka akan mengakibatkan guru cenderung bersikap 
malas-malasan, kurang optimal dalam mengajar sehingga kualitas pendidikan pun akhirnya banyak dipertanyakan.

4. Motivasi kerja berpengaruh positif signifikan terhadap kepuasan kerja guru SMKN 1 Depok dan SMKS Yapan Indonesia. Artinya apabila motivasi kerja guru meningkat, maka akan meningkat pula kepuasan guru. Sebaliknya, apabila motivasi kerja menurun, maka kepuasan kerja pun akan menurun.

5. Motivasi kerja berpengaruh positif signifikan terhadap disiplin kerja, baik secara langsung maupun tidak langsung Artinya apabila motivasi kerja meningkat, maka disiplin kerja pada diri guru cenderung akan meningkat baik secara langsung maupun melalui peningkatan kepuasan kerja guru.

6. Kepuasan kerja berpengaruh positif signifikan terhadap disiplin kerja guru SMKN 1 Depok dan SMKS Yapan Indonesia. Artinya apabila kepuasan kerja guru meningkat, maka akan meningkatkan disiplin kerja guru. Sebaliknya, apabila guru tidak puas dalam bekerja, tidak nyaman dengan suasana kerja, kurang puas dengan promosi atasan yang kurang adil, maka secara otomatis disiplin kerja cenderung akan menurun.

\section{SARAN}

1. Kepada seluruh guru SMKN 1 Depok dan SMKS Yapan Indonesia, hendaknya dalam menggunakan perlengkapan kantor atau fasilitas sekolah dengan baik, misalnya dalam pengunaan infokus, peralatan-peralatan untuk praktek agar mengacu prosedur yang benar. Apabila tidak sengaja merusak perlengkapan kantor agar segera diperbaiki.

2. Kepada seluruh kepala Sekolah SMKN 1 Depok dan SMKS Yapan Indonesia dalam tugas dan fungsinya sebagai pemimpin agar perannya sebagai pemberi visi dan strategi lebih ditingkatkan lagi. Misalnya dalam memberikan tugas kepada guru agar lebih bersifat visioner, mampu memberikan pemecahan masalah dengan strategi yang handal dan mudah dijalankan oleh guru.

3. Kepada guru agar lebih ditingkatkan lagi motivasi kerjanya terutama yang berhubungan dengan dorongan atau kebutuhan dalam mengajar perlu ditingkatkan. Misalnya melalui peningkatan atau penguasaan kompetensi guru,

4. Kepada Kepala Sekolah dan seluruh guru, terutama yang memiliki jabatan struktural agar dalam proses mencapai tujuan organisasi sekolah perlu diperbaiki, sistem manajemen berbasis sekolah harus diimplementasikan, perlu ekskusi tidak hanya 
rencana tinggal rencana, hasilnya nol besar. Sehingga kepuasan kerja terhadap manajemen akan meningkat, terjalin suasana yang kondusif dalam sekolah yang berimplikasi pada peningkatan mutu pendidikan.

5. Kepada peneliti selanjutnya disarankan untuk meneliti faktor-faktor lain yang mempengaruhi disiplin kerja guru.

\section{DAFTAR PUSTAKA}

Arikunto, Suharsimi.2010. Prosedur Penelitian Suatu Pendekatan Praktek. Jakarta: PT Rineka Cipta.

Handoko. T. Hani. 2001. Manajemen Personalia dan Sumber Daya Manusia. Yogyakarta: BumiAksara

Hasibuan. 2007. Organisasi dan Motivasi Edisi ke -5. Jakarta: Diterbitkan PT Bumi Aksara. . 2012. Manajemen Sumber Daya Manusia. Jakarta: Bumi Aksara

Kahar, Irawaty A. 2008. Konsep Kepemimpinan dalam Perubahan Organisasi (Organizational Change) pada Perpustakaan Perguruan Tinggi. Pustaha: Jurnal Studi Perpustakaan dan Informasi Vol.4, No.1

Kohli, Ajay K, Tasadaduq A Shervani and Goutam N Chalagalla. 1998. Learning and Performance Orientation of Salespeople: The Role of Supervisors. Journal of Marketing Research Vol.35, No.2

Luthans, Fred. 2006. Perilaku Organisasi. Yogyakarta: Andi.

Mangkunegara, Anwar Prabu. 2009. Manajemen Sumber Daya Manusia Perusahaan. Bandung: PT Remaja Rosdakarya.

Mathis. 2006. Manajemen Sumber Daya Manusia. Jakarta: Salemba Emapt.

Nasution, M.N. 2004. Manajemen Mutu Terpadu. Bogor: PT. Ghalia Indonesia

Nawawi, Hadari 2003. Manajemen Strategik Organisasi Non Profit Bidang Pemerintahan. Yogyakarta: Gajah Mada Universitas Press.

Ni Nyoman Yuliarmi dan Putu Riyasa, 2009. Analisis Faktor-Faktor yang Mempengaruhi Kepuasan Pelanggan terhadap Pelayanan PDAM Kota Denpasar. Buletin Studi Ekonomi. Volume 12 Nomor 1 Tahun 2007.

Riduwan. 2013. Metode dan Teknik Menyusun Proposal Penelitian. Cetakan ke-5, Bandung: Alfabeta. 
Rivai, Veithzal. 2004. Kepemimpinan dan Perilaku Organisasi. Jakarta: Rajawali Pers.

Robbins, Stephen P. 2006. Perilaku Organisasi. Jakarta: Indeks Kelompok Gramedia.

Robbins, Stephen P and Mary Coulter. 2010. Manajemen Edisi Kesepuluh Jilid Dua. Jakarta : Erlangga

Robert L. Mathis dan John H. Jackson. 2011. Human Resource Management. Jakarta: Salemba Empat.

Ruvendi, Ramlan. 2005. Manajemen Sumbaer Daya Manusia 1. Jakarta: Rineka Cipta.

Sri, Afridola. 2013. Pengaruh Kepemimpinan, Lingkungan Kerja dan Kepuasan Kerja Terhadap Disiplin Kerja Pegawai Dinas Pendidikan Kabupaten Tanah Datar. Tesis. Unand.

Sondang P. Siagian. 2012. Manajemen Sumber Daya Manusia. Jakarta: Bumi Aksara.

Sugiyono. 2009. Statistik Non Parametrik untuk Penelitian. Bandung: Alfabeta.

Thoha, Miftah. 2003. Kepemimpinan Dalam Menajemen Suatu Pendekatan Perilaku, Edisi 1, cetakan 9. Jakarta: Raja Grafindo Persada.

. 2008. Perilaku Organisasi -Konsep Dasar dan Aplikasinya. Jakarta: Raja Grafindo Persada.

. 2012. Kepemimpinan Dalam Menajemen, cetakan 16. Jakarta: Raja Grafindo Persada.

Umar, Husein. 2009. Metode Penelitian untuk Skripsi dan Tesis Bisnis. Jakarta: Rajawali Pers.

Uno, Hamzah B. 2010. Teori Motivasi dan Pengukurannya. Jakarta: Bumi Aksara.

Usman, Husaini. 2010. Manajemen: Teori, Praktek dan Riset Pendidikan. Jakarta: Bumi Aksara 